\title{
Some Musings About the Future of Business Ethics Scholarship
}

\author{
Patricia H. Werhane $e^{1,2,3}$
}

Published online: 29 July 2020

(c) Springer Nature B.V. 2020

As a retiring Consulting Editor for the Journal of Business Ethics and one of the founders of the Society for Business Ethics, I was asked by the editors-in-chiefs to write a small piece outlining where I think scholarship in the field is at the present time and where it is going or should go in the future.

A bit of background: The Journal of Business Ethics was one of the first contemporary journals in business ethics, founder by Alex Michalos and later joined by Deborah Poff. From its beginning the Journal has distinguished itself by appealing to social scientists as well as philosophers and theologians. This is in contrast with some other journals that imagine that normative philosophy has a choke-hold on the field, despite the Business and Society social science-led movement began in the 1960s. Given the original mission, under the present leadership of Ed Freeman and Michelle Greenwood the Journal has reorganized itself with section editors who evaluate papers in their fields of specialization, e.g., organizational behavior, finance, economics, philosophy, theology, etc., as well as considering cross-disciplinary contributions. This reorganization has contributed to a fine collection of articles and reviews from several points of view, advancing the Journal of Business Ethics the distinction of being on the top 50 list in the Financial Times.

So where is this cross-disciplinary scholarship going and what will the field look like in 2050? The Journal has always encouraged special issues on a focused topic. Initiated by a series of sessions on feminism at the Society for Business Ethics meetings in 2019 (and reminiscent of an early Ruffin collection edited by Ed Freeman on this topic) they have announced a new Feminisms and Business Ethics section,. With the current preoccupation with diversity, race, and

Patricia H. Werhane

pwerhane@depaul.edu

1 Professor Emerita, University of Virginia, Charlottesville, VA, USA

2 Professor Emerita, DePaul University, Chicago, IL, USA

3 Gies College of Business, University of Illinois, Champaign, IL, USA equity, these are very positive steps for the Journal. And, in this present climate of anger and protests and given the cross-disciplinary make-up of the Journal editors, this is now the "moment" to broaden the scope across international venues to encourage submissions and special issues on these topics that are inclusive of thinking in emerging as well as mature economies. Indeed, I would encourage research and writing that truly take into account cultural differences as well as race and gender diversity.

Scholarship in the field of business ethics and corporate responsibility in the twenty-first century will, or should, be developing leading thinkers in at least three other areas. These are obvious but always evolving.

Most obviously is environmental sustainability. Very simply put, how can organizations avoid further polluting and indeed invent ways to be completely self-sustaining and nonpolluting while still being profitable? There are a few examples, e.g. Interface Carpet, but thinkers in our field need to explore these possibilities more seriously and with viable proposals for saving our planet and ecosystem and well as being economically viable.

Secondly, and again obviously, we have all written on globalization and the expansion of free enterprise globally. But many of us think of free enterprise as capitalism in Western developed nation terms. Less attention has been extended to think about various forms of free enterprise that are economically viable and at the same time fit local economies and cultures. Journal of Business Ethics has encouraged papers from emerging economies and this encouragement should be extended with special editors from these countries to nudge the development of various topics in business ethics including economics from a more indigenous or developing country point of view.

Moreover, as the Wall Street Journal noted in June, 2020, the coronavirus pandemic has led many nations to rethink about global trade and the unmitigated expansion of global commerce As one commentator argued, "Global capitalism will have to be rebalanced." New trade barriers are being erected and a push for national independence is a theme for many politicians in many countries. At the same time, 
most American and European companies are extraordinarily dependent on a global supply chain.. Medtronic, an American manufacturer of medical devices, for example, claims that its ventilators are made from 1000 parts soured from 14 countries. ${ }^{1}$ So as scholars we should investigate how reframing globalization raises (or settles) fresh sets of ethical issues.

Third, despite the worn-out essays on employee rights, [and I have written many of these!], in the United States the pandemic has again forced us to revisit the questions of unemployment and welfare and an outcry for new models. In Japan, which admittedly suffered fewer virus deaths that many countries, they have paid all workers their regular wages despite the edict to stay home. ${ }^{2}$ This move preserves the dignity of workers and is no more costly than the American "largesse" of doling out monies to the unemployed. Obviously I have some opinions on this subject, but the more important point is that with the advances of technologies that take away jobs and maybe even more pandemics and other crises that create massive unemployment, a new more ethical model that takes into account human dignity as well as welfare funding would be a worthwhile research project.

Finally, and linked to the others, the Conscious Capitalism movement in North America should be an exploding topic in the field but it has not yet been so. Connecting those ideas with environmental sustainability and globalization (and some work in these areas has been done) might be one way to think through bringing to together topics of critical importance for the survival of the field of business ethics, of free enterprise in various formulations, and of the planet.

There is still work to be done.

Publisher's Note Springer Nature remains neutral with regard to jurisdictional claims in published maps and institutional affiliations.

${ }^{1}$ See "Coronavirus Reshapes World Trade" in the Wall Street Journal, June 20-21, 2020, pp. 1, 10.

2 See "Why Japan's Jobless Rate is Just 2.6\%, Even in a Crisis.: New

York Times, June 21, 2020, 4. 